\title{
Studi Korelasional Antara Efektivitas Program Pelatihan dan Kepribadian dengan Kualitas Layanan Guru SMP Swasta Se- Kecamatan Parakansalak Kabupaten Sukabumi
}

\author{
Neneng Nurmilah Arifin*, Widodo Sunaryo**, Djoehana** \\ * Mahasiswa Program Studi Administrasi Pendidikan, Program Pascasarjana \\ ** Staf Dosen Program Studi Administrasi Pendidikan, Program Pascasarjana \\ Universitas Pakuan \\ Bogor, Indonesia
}

Diterima: 170ktober 2015. Disetujui: 28 November 2015. Dipublikasikan: Januari 2016

\begin{abstract}
Abstrak
Penelitian ini bertujuan untuk mempelajari hubungan antara Efektivitas Program Pelatihan dan Kepribadian dengan Kualitas Layanan Guru di SMP Swasta di Kecamatan Parakansalak Kabupaten Sukabumi. Responden penelitian adalah guru non-Pns dengan jumlah sampel 100 orang yang diambil secara proportional random sampling. Penelitian ini merupakan Penelitian ini dikelompokkan dalam penelitian korelasional antara dua variabel bebas yaitu Efektivitas Program Pelatihan dan Kepribadian dan satu variabel terikat yaitu Kualitas Layanan Guru. Metode yang digunakan yaitu metode survei dan teknik analisis data dengan uji statistic korelasi sederhana dan korelasi ganda serta uji regresi linear sederhana, uji regresi linear ganda dan uji korelasi parsial. Dari hasil penelitian ditemukan tiga kesimpulan, yaitu : Pertama, terdapat hubungan positif yang sangat signifikan antara Efektivitas Program Pelatihan dengan Kualitas Layanan Guru dengan koefisien korelasi ry1 = 0,7116, dan koefisien determinasi ry21 = 0,5064 yang berarti kontribusi Efektivitas Program Pelatihan terhadap Kualitas Layanan Guru sebesar $50,64 \%$ dan persamaan regresi $\hat{Y}=70,5593+0,6009 X_{1}$. Kedua, terdapat hubungan positif yang sangat signifikan antara Kepribadian dengan Kualitas Layanan Guru dengan koefisien korelasi ry1 =0,6883, dan koefisien determinasi ry21 $=0,4738$ yang berarti kontribusi Efektivitas Program Pelatihan terhadap Kualitas Layanan Guru sebesar $47,38 \%$ dan persamaan regresi $\hat{Y}=68,5838+0,6142 X_{2}$. Ketiga, terdapat hubungan positif yang sangat signifikan antara Efektivitas Program Pelatihan dan Kepribadian secara bersama-sama dengan Kualitas Layanan Guru dengan koefisien korelasi ry. $12=0,7143$, dan koefisien determinasi ry2.12 =0,5102 yang berarti kontribusi Efektivitas Program Pelatihan terhadap Kualitas Layanan Guru sebesar 51,02\% dan persamaan regresi $\hat{Y}=67,958+$ $0,6009 X 1+0,1537 X_{2}$. Berdasarkan hasil penelitian di atas, dapat disimpulkan bahwa Kualitas Layanan Guru dapat ditingkatkan melalui Efektivitas Program Pelatihan dan Kepribadian.
\end{abstract}

C 2016 Program Pascasarjana Universitas Pakuan

KATA KUNCI: Program Pelatihan Dan Kepribadian, Kualitas Layanan Guru

PENDAHULUAN

Pendidikan di era modern dewasa ini harus diselenggarakan secara optimal untuk menghasilkan lulusan (out put) sesuai dengan yang diharapkan semua pihak, mengingat maju dan mundur sebuah bangsa tergantung pada pendidikan bangsa 
tersebut. Keberhasilan meraih tujuan pendidikan bisa dikatakan tergantung pada keberhasilan sekolah dalam mendidik para peserta didiknya. Kegiatan dalam proses pendidikan dan pembelajaran menuntut kualitas dan kemampuan para pendidik yang bertujuan membentuk dan mengembangkan watak peradaban bangsa yang maju dan mandiri.

Kemajuan dalam bidang pendidikan menuju pada perbaikan kualitas pendidikan dan menuntut tingginya kinerja lembaga pendidikan dengan mengacu pada perbaikan kualitas yang berkelanjutan, kreativitas, dan produktivitas pegawai (guru). Kualitas bukan saja pada unsur masukan (input) tetapi juga unsur proses, terutama pada unsur keluaran (output) atau lulusan, agar dapat memuaskan harapan masyarakat pelanggan pendidikan.

Dalam era persaingan di dunia pendidikan yang sangat kompetitif dan untuk menumbuhkan kepercayaan masyarakat terhadap lembaga pendidikan, dibutuhkan suatu strategi bersaing yang tepat agar mampu mempertahankan posisinya dalam pasar. Salah satu strategi bersaing yang paling tepat diterapkan saat ini adalah dengan meningkatkan Kualitas Layanan di sekolah.

Kualitas Layanan merupakan suatu bentuk penilaian konsumen terhadap tingkat layanan yang diterima (perceived service) dengan tingkat pelayanan yang diharapkan (expected service). Definisi Kualitas Layanan berfokus pada upaya pemenuhan kebutuhan dan keinginan pelanggan serta ketepatan penyampaiannya untuk mengimbangi harapan pelanggan. Kepuasan pelanggan mengungkapkan keselarasan antara harapan seseorang dan hasil yang diperoleh, yang di dalamnya pemakai turut berpartisipasi.
Model Layanan yang berkualitas tidak terbatas pada layanan peserta didik (pemasaran eksternal) berupa perhatian dan peningkatan proses pembelajaran, kelancaran alur konsultatif, penyediaan bahan bacaan (perpustakaan), sarana dan prasarana yang memadai serta media pembelajaran yang cukup, melainkan pelayanan keadilan (pemasaran internal dan pemasaran interaktif) sehingga dari dua bentuk pelayanan tersebut akan memberikan arti sebagai berikut : pada pemasaran eksternal menggambarkan aktivitas normal yang dilakukan oleh lembaga dalam memberikan pelayanan kepada peserta didik sebagai pelanggan. Pemasaran internal menggambarkan tugastugas lembaga dalam rangka memotivasi dan meningkatkan profesi staf dengan memberikan penghargaan yang sepadan, adil, serta manusiawi. Sedangkan pemasaran interaktif menggambarkan interaksi di antara pelanggan yaitu para peserta didik dan guru (Service Quality). Bila gambaran di atas, dapat terealisasi dengan baik maka pelanggan akan merasa puas sehingga jalinan komunikasi dan saling membutuhkan antara pelayan dengan pelanggan berlangsung secara berkesinambungan.

Program Layanan Guru saat ini menjadi pusat perhatian dari kebijakan organisasi jasa termasuk pendidikan sekolah, dalam rangka memperoleh keunggulan persaingan yang makin ketat, sehingga setiap organisasi sekolah berusaha semaksimal mungkin untuk memberikan layanan pada masyarakat pengguna jasa pendidikan dengan biaya yang cukup tinggi.

Saat ini kebijakan organisasi jasa lebih menekankan pada Kualitas Layanan untuk membangun kepercayaan dalam menjaga hubungan antara produk jasa dan pengguna jasa melalui layanan yang 
berkesinambungan, demikian juga strategi sekolah dalam membuat kebijakan tidak terlepas dari program-program layanan yang bertujuan untuk menjaga hubungan antara guru dan peserta didik. Persaingan sistem layanan dari berbagai lembaga pendidikan mulai diuji, bahwa meningkatnya intensitas dan tingkat persaingan biasanya juga diikuti dengan tingginya Kualitas Layanan Guru.

Layanan Guru merupakan urutan kegiatan- kegiatan guru melalui sistem penyediaan bantuan kepada siswa dalam upaya perbaikan yang berkesinambungan dan cocok untuk digunakan dalam membantu dan memenuhi kebutuhan dalam menyelesaikan masalah-masalah belajar peserta didiknya, dalam kesinambungan dan kecocokan tersebut merupakan wujud pemenuhan kebutuhan layanan guru yang baik pada peserta didiknya.

Pada dasarnya Landasan Layanan Guru adalah memberikan layanan terbaik untuk kepuasan peserta didik, sebagai premis dari proses pengelolaan pelayanan yang dituntut untuk selalu mempertahankan kepuasan peserta didik dalam mencapai prestasi belajarnya. Prestasi belajar tersebut merupakan cermin dari layanan guru, dengan kata lain, bila layanan guru baik, maka prestasi belajar peserta didik baik. Oleh sebab itu prestasi belajar peserta didik sejalan dengan kualitas layanan yang dilakukan oleh guru.

Layanan memerlukan keterampilan tertentu, Layanan Guru sangat erat hubungannya dengan tugas mengajar yang dilakukan oleh guru, yaitu relevansi antara bidang pembelajaran dengan kegiatan belajar peserta didik. Sehingga memerlukan pemahaman karakteristik hubungan antara bidang pembelajaran yang diberikan oleh guru dengan peserta didik sebagai pembelajar harus diadaptasikan sampai mencapai kecocokan yang bermanfaat bagi kepentingan prestasi belajar peserta didiknya.

Pengamatan sehari-hari, bahwa Layanan Guru pada peserta didik masih relatif rendah, hal ini ditandai dengan adanya pembelajaran guru yang kurang efektif, mereka hanya melakukan pembelajaran sekedar menyelesaikan kurikulum, tanpa mendeteksi untuk memenuhi kebutuhan peserta didiknya. Hal tersebut perlu penanganan yang serius untuk meningkatkan layanan guru di Sekolah- Sekolah. Selain itu perlu adanya jaminan layanan guru sebagai upaya untuk membentuk kesan, agar orientasi sekolah yang diwakili oleh guru memperoleh keyakinan dan kepercayaan penuh dari peserta didik dan orang tuanya, sehingga jalinan hubungan antara peserta didik dan organisasi sekolah sebagai produk pelayanan dapat memperoleh loyalitas dari peserta didik dan masyarakat pengguna jasa pendidikan. Tumbuhnya loyalitas masyarakat dan peserta didik didasari oleh persepsinya, dimana persepsi peserta didik tentang pelayanan merupakan dasar dari suatu perangkat yang kompleks, dari hasil pengalaman langsung dan hubungan dengan organisasi sekolah terhadap muatan isu-isu prestasi belajar peserta didik dan profesional gurunya.

Hasil survei pendahuluan terhadap tiga SMP swasta di wilayah Kecamatan Parakansalak pada awal April 2015 , Kepala Sekolah Empat SMP tersebut menilai bahwa Kualitas Layanan Guru SMP di Kecamatan Parakansalak masih belum optimal antara lain :

1. $59 \%$ guru belum memuaskan dalam hal datang tepat waktu sesuai jadwal pembelajaran di kelas. 
2. $55 \%$ guru belum optimal dalam hal melaksanakan program remedial bagi peserta didik yang dinilai kurang.

3. $52 \%$ guru belum maksimal dalam hal menyelesaikan kelengkapan administrasi pembelajaran.

4. $60 \%$ guru mengajar mata pelajaran yang tidak sesuai dengan latar belakang pendidikannya.

5. $59 \%$ guru belum memuaskan dalam melakukan kunjungan rumah (home visit) kepada peserta didik yang bermasalah di sekolah.

6. $66 \%$ guru tidak optimal dalam hal menggunakan fasilitas laboratorium IPA untuk meningkatkan pembelajaran yang efektif

Kondisi lapangan guru SMP Swasta di wilayah Kecamatan Parakansalak memerlukan penyelesaian masalah untuk dicarikan solusi yang tepat dan paling tidak diharapkan meminimalkan permasalahanpermasalahan yang terjadi, sehingga di masa yang akan datang dapat meningkatkan Kualitas Layanan Guru yang lebih baik untuk meningkatkan kualitas pembelajaran di lingkungan sekolah. Upaya untuk meningkatkan layanan guru dalam pembelajaran tersebut perlu dilakukan pengamatan dan penelitian yang mendalam.

Dalam artikel ini akan dibahas tentang hubungan positif antara Efektivitas Program Pelatihan dengan Kualitas Layanan Guru, hubungan positif antara Kepribadian dengan Kualitas Layanan Guru, hubungan positif antara Efektivitas Program Pelatihan dan Kepribadian secara bersama-sama dengan Kualitas Layanan Guru.

\section{METODE}

Penelitian ini menggunakan pendekatan kuantitatif dengan metode survei, yaitu penelitian yang ditujukan untuk mengkaji populasi besar maupun kecil dengan menyeleksi dan mengkaji sampel yang dipilih dari populasi itu untuk menemukan insidensi, distribusi, dan interrelasi relative dari variable-variabel.

Data yang digunakan merupakan data kuantitatif yang berasal dari hasil survey berupa penyebaran kuesioner kepada sampel guru SMP Swasta yang menjadi responden. Jumlah sampel adalah 100 orang yang mewakili populasi 133 orang guru dari 7 SMP. Sampel diambil dengan rumus taro Yamane. Sebelum digunakan data tersebut diuji validitasnya dengan metode korelasi pearson dan reliabilitasnya dengan menggunakan Alpha Cronbach. Uji persyaratan analisis dilakukan dengan uji normalitas, uji homogenitas dan uji linearitas data.

\section{HASIL DAN PEMBAHASAN}

\section{A. Hubungan antara Efektivitas Program Pelatihan dengan Kualitas Layanan Guru}

Berdasarkan hasil analisis uji korelasi antara data Efektivitas Program Pelatihan dengan data Kualitas Layanan Guru diperoleh skor koefisien korelasi (ry1) = 0,7116 dan skor koefisien determinasi (ry12) $=0,5064(50,64 \%)$. Hasil analisis tersebut menunjukkan bahwa terdapat hubungan positif yang sangat signifikan antara Efektivitas Program Pelatihan dengan Kualitas Layanan Guru, hubungan tersebut merupakan hubungan fungsional yang memiliki arti bahwa Kualitas Layanan Guru dapat ditingkatkan melalui peningkatan Program Pelatihan yang efektif. Hal ini menunjukkan bahwa sebesar 50,64\% Kualitas Layanan Guru dapat ditingkatkan melalui peningkatan Efektivitas dalam Program Pelatihan untuk Guru. 
Menurut Wilson Pelatihan adalah proses yang direncanakan untuk memodifikasi sikap, pengetahuan atau keterampilan melalui pengalaman belajar untuk mencapai kinerja yang efektif dalam satu atau berbagai kegiatan. Tujuannya adalah untuk mengembangkan kemampuan individu dan memenuhi kebutuhan organisasi saat ini dan di masa depan. Menurutnya ada lima faktor strategis Program Pelatihan, yaitu identifikasi kebutuhan pelatihan, perumusan tujuan pelatihan, perencanaan dan perancangan pelatihan, pelaksanaan pelatihan, penilaian dan evaluasi pelatihan. Sedangkan Menurut Noe et al., Pelatihan adalah upaya yang direncanakan untuk mempermudah pembelajaran para karyawan tentang pengetahuan, keterampilan dan perilaku yang berkaitan dengan pekerjaan. Adapun Proses Perancangan Pelatihan terdiri dari analyisis yaitu penilaian kebutuhan pelatihan, design yaitu Perancangan Program Pelatihan, development yaitu Pengembangan Program Pelatihan, implementation yaitu Pelaksanaan Program Pelatihan dan evaluation yakni evaluasi Pelatihan.

Berdasarkan dua pendapat tersebut, jelas bahwa Program Pelatihan yang efektif sangat berpengaruh kepada Kualitas Layanan seseorang, semakin tinggi Efektivitas Program Pelatihan yang dicapai, maka akan semakin tinggi tingkat pengetahuan dan keterampilan seseorang dan akan berdampak pada semakin tingginya Kualitas Layanan yang diberikan. Seorang guru yang mengikuti Program Pelatihan yang efektif akan meningkat dan berkembang pengetahuan dan keterampilannya. Hal ini akan berpengaruh pada kemampuannya untuk bekerja profesional dan maksimal dengan penuh dedikasi sehingga akan meningkatkan konsistensi dan kehandalannya dalam memberikan Kualitas Layanan (Service Quality).

B. Hubungan antara Kepribadian dengan Kuaitas Layanan Guru

Berdasarkan hasil analisis uji korelasi antara data kepribadian dengan data kualitas layanan guru diperoleh skor koefisien korelasi (ry2) $=0,6883$ dan skor koefisien determinasi (ry22) $=0,4738$ (47,38\%). Hasil analisis tersebut dapat dideskipsikan bahwa bahwa terdapat hubungan positif yang sangat signifikan antara Kepribadian dengan Kualitas Layanan Guru, hubungan tersebut merupakan hubungan fungsional yang memiliki arti bahwa Kualitas Layanan Guru dapat ditingkatkan melalui peningkata Kepribadian Guru. Hal ini terlihat dari hasil perhitungan koefisien korelasi antara variabel Kepribadian Guru dengan Kualitas Layanan Guru. Hal ini menunjukkan bahwa sebesar 47,38\% Kualitas Layanan Guru dapat ditingkatkan melalui dorongan dalam diri guru untuk berkepribadian.

Menurut Gibson, et.al., Kepribadian adalah seperangkat karakteristik, kecenderungan, dan temperamen (individu) yang relatif stabil dan secara signifikan dibentuk oleh faktor genetik/turunan, faktor-faktor sosial, budaya dan lingkungan. Menurutnya, Kepribadian memiliki 5 dimensi: a. Kesadaran b. Keterbukaan c. Keramahan d. Kestabilan emosi dan e. Keterbukaan terhadap pengalaman.

Sedangkan Menurut Kinicki dan Williams Kepribadian terdiri dari ciri-ciri psikologis stabil dan atribut perilaku yang memberikan identitas seseorang. Menurutnya ada lima dimensi kepribadian, yaitu a. Keterbukaan, memiliki prilaku 
banyak bicara, mudah bergaul, dan tegas, $b$. Keramahan. terpercaya, baik hati, kooperatif, dan berhati lembut, c. Kesadaran, memiliki prilaku dapat diandalkan, bertanggung jawab, berorientasi prestasi, dan gigih, d. Kestabilan emosi memiliki karakter santai, aman, dan tidak gelisah dan e. Keterbukaan terhadap pengalaman memiliki kemampuan intelektual, imajinatif, penasaran, dan wawasan yang luas.

Berdasarkan dua pendapat di atas jelas bahwa kepribadian dalam diri seseorang sangat berpengaruh terhadap kualitas layanannya. Semakin kuat dorongan untuk mencapai pribadi terbaik, akan semakin kuat ia berusaha untuk mencari solusi dari setiap permasalahan yang dihadapinya dan berusaha untuk bertanggung jawab dalam memberikan layanan terbaik. Seorang guru yang memiliki kepribadian tinggi akan terus berusaha untuk menambah wawasan dan pengetahuan kemudian mengaplikasikannya dalam melakukan tugasnya sebagai guru memberikan layanan terbaik kepada anak didiknya, akan selalu berusaha menjadi pribadi yang unggul dan professional, sehingga kepribadiannya akan meningkatkan kehandalannya dalam memberikan kualitas layanan.

C. Hubungan antara Efektivitas Program Pelatihan dan Kepribadian secara Bersama-sama dengan Kualitas Layanan Guru

Hasil penelitian menunjukkan bahwa terdapat hubungan yang sangat signifikan antara Efektivitas Program Pelatihan dan Kepribadian secara bersama-sama dengan Kualitas Layanan Guru yang disajikan dalam persamaan regresi $\hat{Y}=67,958+0,4663_{\times 1}+$ $0,1537 \times 2$ hubungan tersebut merupakan hubungan fungsional yang memiliki arti bahwa setiap penambahan 1 unit Efektivitas Program Pelatihan dan 1 unit Kepribadian Guru secara bersama-sama akan meningkatkan Kualitas Layanan Guru sebesar 0,62 unit.

Mencermati hasil pengujian keberartian Persamaan regresi ganda diperoleh Fhitung $=50,527$ dengan Ftabel (a $=0,05)=3,092$ dan Ftabel $(a=0,01)=4,8309$ , terlihat bahwa Fhitung > Ftabel. Hal ini dapat disimpulkan bahwa persamaan regresi $\hat{Y}=67,958+0,4663_{x 1}+0,1537 \times 2$ adalah berarti.

Lebih lanjut dari hasil keberartian persamaan regresi ganda diperoleh Fhitung > Ftabel, dapat disimpulkan bahwa terdapat hubungan positif yang sangat signifikan antara Efektivitas Program Pelatihan dan Kepribadian secara bersama-sama dengan Kualitas Layanan Guru. Artinya apabila Efektivitas Program Pelatihan dan Kepribadian guru meningkat secara bersama-sama maka akan terjadi peningkatan terhadap Kualitas Layanan Guru.

Adapun tingkat kekuatan hubungan antara Efektivitas Program Pelatihan dan Kepribadian secara bersama-sama dengan Kualitas Layanan Guru dapat dilihat dari nilai koefisien determinasi korelasi ganda yang menerangkan seberapa besar persentase kedua variabel bebas tersebut menentukan Kualitas Layanan Guru. Hasil penelitian menunjukkan bahwa koefisien determinasi korelasi ganda antara Efektivitas Program Pelatihan dan Kepribadian secara bersamasama dengan Kualitas Layanan Guru adalah r2y12 $=0,5041$ skor koefisien determinasi menunjukkan bahwa $50,41 \%$ Kualitas Layanan Guru dapatdijelaskan oleh variabel Efektivitas Program Pelatihan dan Kepribadian secara bersama-sama. 
Menurut Wyckof dalam Arief, Kualitas Layanan (jasa) adalah tingkat keunggulan yang diharapkan dan pengendalian atas tingkat keunggulan tersebut untuk memenuhi keinginan pelanggan. Keunggulan tersebut dapat diraih dengan meningkatkan sumber daya manusia melalui pelatihan. Menurut Dessler, pelatihan mengajarkan karyawan berbagai keterampilan dasar yang mereka butuhkan untuk menjalankan pekerjaan mereka. Pelatihan merupakan salah satu usaha dalam meningkatkan mutu sumber daya manusia dalam dunia kerja. Karyawan, baik yang baru ataupun yang sudah bekerja perlu mengikuti pelatihan karena adanya tuntutan pekerjaan yang dapat berubah akibat perubahan lingkungan kerja, strategi, dan lain sebagainya.

Stephen P. Robbins dan Timothy A. Judge menyatakan bahwa Kepribadian merupakan keseluruhan cara dimana seorang individu bereaksi dan berinteraksi dengan individu lain. Kepribadian mempunyai peran dalam kemampuan seseorang memberikan Kualitas Layanan. Penelitian menunjukkan bahwa individu yang mempunyai kepribadian negative (misalnya seseorang yang cenderung galak, tidak mampu bersepakat, antagonistic, mudah bingung, cemas, tertekan dan tidak nyaman) biasanya tidak dapat memberikan kualitas layanan yang memuaskan. Hal ini berarti bahwa individu yang berkepribadian positif (misalnya seseorang yang cenderung ramah, tegas, mampu bersosialisasi, bersepakat, bertanggung jawab, tenang, kreatif, gigih dan percaya diri) biasanya mampu memberikan Kualitas Layanan yang memuaskan.

Berdasarkan dua pendapat tersebut, peran pelatihan yang efektif dalam meningkatkan sumber daya manusia yang berdampak pada peningkatan kualitas layanan sangat penting untuk dilaksanakan, terlebih lagi kemajuan dalam dunia pendidikan yang semakin pesat menuntut seorang guru untuk selalu meningkatkan wawasan, pengetahuan dan kemampuannya agar mampu menjalankan tugasnya dengan baik dan bekerja profesional, mampu memberikan solusi atas masalah-masalah yang timbul dalam pekerjaannya, menjadi pribadi yang unggul dan mampu memberikan kualitas layanan terbaik bagi para peserta didik.

Kualitas Layanan guru dipengaruhi oleh kepribadian guru, seorang yang memiliki kepribadian tinggi akan selalu kreatif, suka bersosialisasi, bertanggung jawab, ramah, sopan dan berusaha mencari tentang hal-hal yang baru dan mengaplikasikannya dalam pembelajaran dikelas, sehingga Para peserta didik dapat menerima kualitas layanan yang memuaskan.

\section{PENUTUP}

Berdasarkan hasil pengujian hipotesis dan pembahasannya yang telah diuraikan di atas dapat disimpulkan bahwa: 1. Terdapat hubungan positif yang sangat signifikan antara Efektivitas Program Pelatihan dengan Kualitas Layanan Guru dan kontribusi Efektivitas Program Pelatihan terhadap Kualitas Layanan Guru sebesar 50,64\%; 2. Terdapat hubungan positif yang sangat signifikan antara Kepribadian Guru dengan Kualitas Layanan Guru dan kontribusi Efektivitas Program Pelatihan terhadap Kualitas Layanan Guru sebesar 47,38\%; 3. 3. Terdapat hubungan positif yang sangat signifikan antara Efektivitas Program Pelatihan dan Kepribadian secara bersamasama dengan Kualitas Layanan Guru dan terdapat kontribusi dari variabel Efektivitas 
Program Pelatihan dan kepribadian secara bersama-sama terhadap Kualitas Layanan Guru sebesar 50,41\%.

Sejalan dengan temuan di atas, dapat disimpulkan bahwa (a) Efektivitas Program Pelatihan dan (b) Kepribadian merupakan faktor-faktor determinan terhadap Kualitas Layanan Guru. Dengan kata lain, Kualitas Layanan Guru dapat ditingkatkan melalui pembenahan faktor-faktor: (a) Efektivitas Program Pelatihan dan (b) Kepribadian, baik secara sendiri-sendiri maupun secara bersama-sama.

\section{DAFTAR PUSTAKA}

Arief. (2007). Pemasaran Jasa dan Kualitas Pelayanan. Malang: Bayumedia

Baldwin., Bommer \& Rubin. (2008). Developing Management Skills What Great Manager Know and Do. NewYork : McGraw Hill

Chris Fill, B.P \& Page, K. (2011) Marketing, New York : Oxford University Press

Colquitt, J.A., Lepine \& Wesson, M.J. (2011). Organizational Behavior. NewYork : McGrawHill.

Dessler \& Gary. (2008). Human Resource Management. Upper Saddle River, NJ : Pearson Education, 2008

George., Jenifer, M. \& Jones, G.R. (2012). Understanding and Managing Organizational Behavior. New Jersey : Pearson Education

Gibson, J.L., Donnelly, J.H., Ivancevich, J.M \& Konopaske, R. (2012). Organizations Behavior, Structure, Processes. Singapore: Fourteenth Edition

Ivancevich, J.M. (2010). Human Resource Management. New York : McGraw-Hill

Kinicki, A \& Williams, B.K. (2008) Management Practical Introduction. Third edition, New York : McGraw-Hill

Komariah, A \& Triatna, C. (2008). Visionary Leadership Menuju Sekolaf Efektif, Jakarta : Bumi Aksara

Kotler, P. (2000). Marketing Management. New Jersey, Upper Saddle River, NJ : Prentice Hall

Mangkunegara, A.P. (2011). Manajemen Sumber Daya Manusia Perusahaan, Bandung, P.T. Remaja Rosda Karya
Mathis, R.L \& Jackson, Human Resource Management, Nineth Edition. Mason, $\mathrm{OH}$ : Cengage Learning

Mulyasa, E. (2005). Menjadi Guru Profesional Menciptakan Pembelajaran Kreatif dan Menyenangkan. Bandung : PT. Remaja Rosda Karya.

Retnowati, R. (2008). Metodologi Penelitian. Bogor: Program Pascasarjana Universitas Pakuan

Riduwan \& Sunarto. Pengantar Statistika Untuk Penelitian Pendidikan, Sosial, Ekonomi, Komunikasi, dan Sosial. Bandung : Alfabeta, 2009

Sachdev, Sheetal B \& Harsh V. Verma. (2004). Relative Importance of Service Quality Dimension : A Multisectoral Study. Journal of Service Research, Institute of International Management And Technology,

Sallis, E. (2008). Total Quality Management in Education. Yogyakarta: IRCiSoD

Sedarmayanti. (2012). Manajemen dan komponen terkait lainnya, Bunga rampai dan kumpulan bahan ceramah serta presentasi di forum Nasional, Pascasarjana, orasi ilmiah dan lainlain. Bandung: PT. Refika Aditama, 2012.

Shane, Mc \& Glinow, V. (2011). Organiztional Behaviour. USA: University Press.

ugiyono, Statistika Untuk Penelitian, Bandung : Alfabeta, 2010

Suhardan, D. (2010). Supervisi Profesional. Bandung : Alfabeta

Warsita, B. (2008). Teknologi Pembelajaran Landasan dan Aplikasinya. Jakarta: Rineka Cipta 